\title{
Neuroregeneration in neurodegenerative disorders
}

\author{
Ana M Enciu', Mihnea I Nicolescu ${ }^{1,2}$, Catalin G Manole ${ }^{1,2}$, Dafin F Mureşanu ${ }^{3}$, Laurențiu M Popescu ${ }^{1,2}$ and \\ Bogdan O Popescu ${ }^{2,4^{*}}$
}

\begin{abstract}
Background: Neuroregeneration is a relatively recent concept that includes neurogenesis, neuroplasticity, and neurorestoration - implantation of viable cells as a therapeutical approach.

Discussion: Neurogenesis and neuroplasticity are impaired in brains of patients suffering from Alzheimer's Disease or Parkinson's Disease and correlate with low endogenous protection, as a result of a diminished growth factors expression. However, we hypothesize that the brain possesses, at least in early and medium stages of disease, a "neuroregenerative reserve", that could be exploited by growth factors or stem cells-neurorestoration therapies.
\end{abstract}

Summary: In this paper we review the current data regarding all three aspects of neuroregeneration in Alzheimer's Disease and Parkinson's Disease.

\section{Background}

Adult neuroregeneration is a complex concept, beyond the common knowledge of neurogenesis that also comprises endogenous neuroprotection leading to neuroplasticity and neurorestoration -a therapeutical approach of implantation of viable cells (Figure 1). Regeneration in the central nervous system (CNS) implies that new neurons, generated either through proliferation of endogenous stem/progenitor cells or by administration of exogenous stem/precursor cells with potential to substitute for lost tissue, will differentiate, survive, and integrate into existing neural networks [1]. Among the three components of neuroregeneration previously mentioned, neuroplasticity was the first one put forward, by Ramon y Cajal, in 1894: "associations already established among certain groups of cells would be notably reinforced by means of the multiplication of the small terminal branches of the dendritic appendages and axonal collaterals; but, in addition, completely new intercellular connections could be established thanks to the new formation of [axonal] collaterals and dendrites." [2]. However, Ramon y Cajal discards, in the same paper,

\footnotetext{
* Correspondence: bogdan.popescu@jcmm.org

'Laboratory of Molecular Medicine, 'Victor Babeș' National Institute of Pathology, 99-101 Splaiul Independenței, sector 5, Bucharest 050096, Romania

Full list of author information is available at the end of the article
}

the possibility of cell renewal: "it is known that the nerve cells after the embryonic period have lost the property of proliferation". Adult neurogenesis was proposed by Joseph Altman in the 1960's, in a series of articles involving tritiated thymidine retaining cells in the rat brain [3-5]. The newly emerged concept was a controversy until the early 1990s, when several reports [6-9] proved beyond doubt the existence of adult neural stem cells.

The concepts of neuroplasticity and neural stem cells led to the idea of neurorestoration as an alternative therapy for neurodegenerative disorders such as Alzheimer's Disease (AD) and Parkinson's Disease (PD), both characterized by neuronal loss. Our review will attempt to answer the question "Is there any neuroregeneration in neurodegeneration?" taking into account the three concepts mentioned above.

\section{Discussion}

Neurogenesis in neurodegenerative diseases

The adult mammalian brain retains a limited capacity of neurogenesis, which manifests in the subventricular zone (SVZ) and subgranular zone of the hippocampal dentate gyrus. The neuronal precursors migrate into the olfactory bulb, the granular cell layer, or, if necessary, to the striatum, CA1 region of hippocampus or cerebral cortex [10]. 


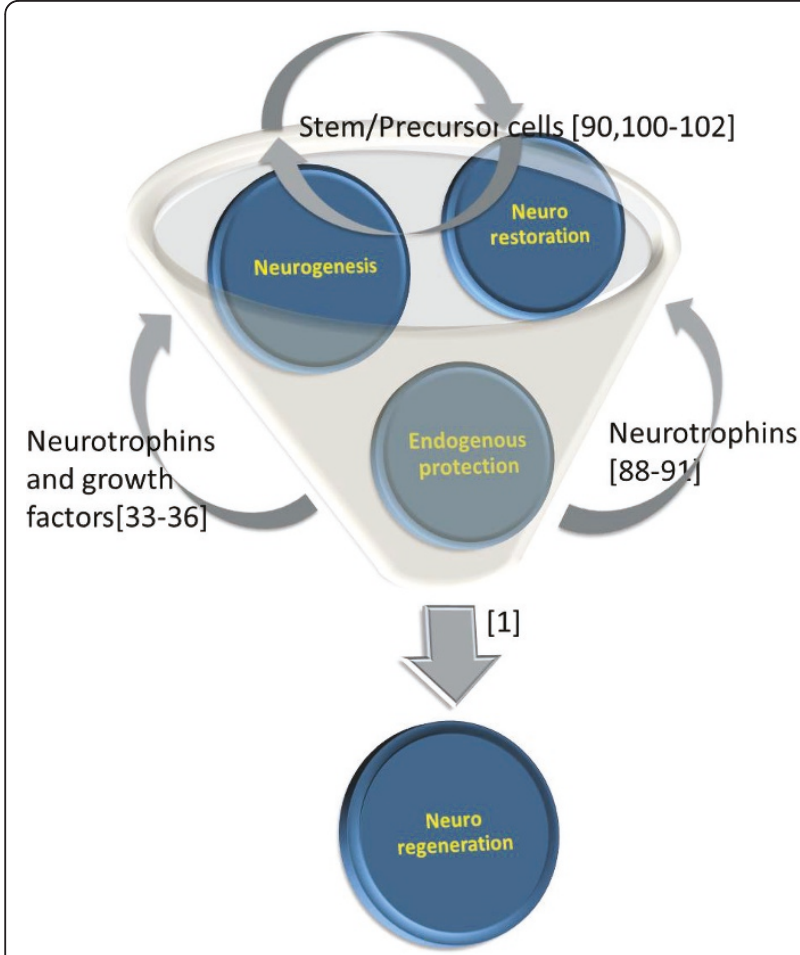

Figure 1 The large concept of neuroregeneration contains three landmarks: endogenous protection by growth factors, neurogenesis and neurorestoration. Rather than perceiving them as isolated events, they should be viewed interrelated, one creating the premises for generating the other.

\section{Alzheimer's Disease animal models}

Neurogenesis in AD transgenic mice is usually impaired, but the results may differ from one transgenic strain to another [11]. Haughey et al. reported that proliferation and survival of neural precursor cells (NPC) was reduced in the dentate gyrus of APP mutant mice with already constituted amyloid deposits [12]. Furthermore, the decrement in NPC number was correlated with accumulation of $A \beta$, even in oligomeric, diffusible form [11]. Although Kolecki et al. confirmed the previous results, they reported that overexpressing APP and $A \beta$ in transgenic mice do not interfere with the mitotic activity of NPC, as assessed by Ki-67 [13].

In vitro, $\mathrm{A} \beta$ effects reported on mouse brain-derived neurospheres are different with the type of peptide used: i) $\mathrm{A} \beta$ 25-35 induces neuronal differentiation and apoptosis in neural committed cells [14]; ii) A $\beta 40$ promotes neurogenesis in NPCs [15]; iii) A $\beta 42$ stimulates neurosphere formation and increases the number of neuronal precursors [16]; it also has a reported effect of inducing astrocytic differentiation [15].

\section{Evidence of neurogenesis in $A D$ human brain}

An overexpression of neurogenesis markers (Doublecortin - DCX, Polysialylated Neural Cell Adhesion Molecule
- PSA-NCAM and TUC-4) in hippocampus of AD patients, without a correlated increase in mature neuronal markers (NeuN, Calbinding D28k) is reported by Jin et al. [17]. This expression disjunction sustains the hypothesis of AD as a failed attempt of precursor cells to neuronal differentiation [18], but Boekhoorn et al argue that DCX is a nonspecific marker, increased due to reactive gliosis [19]. Furthermore, Verwer et al. questioned whether DCX + cells are indeed neuroblasts, presenting arguments for their astrocytic origin [20]. Investigating Musashi1 immunoreactivity in SVZ of AD patients, Ziabreva et al. also reported impaired neurogenesis, as compared to controls [21]. In turn, although Lovell et al. isolated viable NSC from AD patients' hippocampi, they obtained decreased viable NPC yields and altered division rates, as compared to controls [22].

In vitro studies using human neurospheres reported, unlike in vitro models using rodent NPCs, that A $\beta$ 1-40 treatment impaired proliferation and differentiation of precursor cells [23].

In order to assess neurogenesis in AD brain, adding to contradictory results in literature, one must further take into account the neurogenesis-stimulating effect of $\mathrm{AD}$ medication [24].

\section{Neurogenesis in PD animal models}

Adult mice substantia nigra contains bromodeoxyuridine (BrdU) incorporating cells that show dividing and differentiating properties. In vivo, this potential seems to materialize into glial lineage, whereas in vitro, under appropriate growth factors stimulation, neuronal progenitors may be identified [25]. Reports regarding neurogenesis in 6-hydroxydopamine (6-OHDA) models of PD showed increased number of BrdU+ cells and a tendency to migrate towards the lesioned striatal nuclei [26], but without further differentiation on neural lineage [27].

Transgenic mice overexpressing human mutated $\alpha$ synuclein exhibited reduced BrdU+ cells and decreased survival of newly generated neurons, as compared to aged-matched controls. Interestingly, the cessation of $\alpha$ synuclein overexpression led to recovered neurogenesis [28].

\section{Neurogenesis in PD human brain}

The numbers of proliferating cells in the subependymal zone and neural precursor cells in the subgranular zone and olfactory bulb are reduced in postmortem brains of Parkinson's Disease patients [29]. However, there are reports of newly generated neuroblasts PSA-NCAM + in substantia nigra of PD patients, without a solid proof of further dopaminergic neuronal differentiation or reintegration in neuronal circuitry [30].

\section{Endogenous neuroprotection and growth factors}

Discovery of growth factors and their pro-survival effect led to a closer investigation of specific nervous system 
cytokines - Nerve Growth Factor (NGF), Brain-Derived Nerve Factor (BDNF), Glial-Derived Nerve Factor (GDNF) - involvement in the outcome of neurodegenerative diseases. Interestingly, different neuronal subpopulations require different growth factors to thrive, for example NGF protects cholinergic neurons from various insults [31], whereas for dopaminergic neurons, this effect is better sustained by BDNF [32].

Neurotrophins (NGF, BDNF, neurotrophin 3 - NT3 and neurotrophin 4 - NT 4) are most studied for their involvement in normal central nervous system (CNS) development [33-36] and in normal [37] or pathological ageing [38-40]. They exert their effect through tropomyosin-related kinase (Trk) receptors and activation of several signaling cascades: i) IP3-DAG and subsequent release of calcium, leading to synaptic plasticity; ii) PI3K/Akt and transcription of prosurvival genes and iii) MAPK/ERK and activation of differentiation promoting substrates [41]. With low affinity and also in immature form (as proneurotrophins) they interact with p $75^{\mathrm{NTR}}$ a tumor necrosis factor receptor which, in turn, upon activation, leads to apoptosis in neuronal and non-neuronal cells [42]. Glial -Derived Neurotrophic Factor (GDNF) is a growth factor from the transforming growth factor $\beta$ (TGF $\beta$ ) superfamily, with documented neuroprotective effects in dopaminergic neurons cell cultures [43], in vivo studies on laboratory animals [44] and in animal models of PD [45,46]. It exerts its effects through Ret receptor tyrosine kinase and GDNF family receptor $\alpha 1$ (GFR $\alpha 1$ ) complex [47], although the role of Ret signaling is controversial $[48,49]$. Mesencephalic Astrocyte-Derived Neurotrophic Factor (MANF) and Conserved Dopamine Neurotrophic Factor (CDNF) are members of a novel, evolutionarily conserved neurotrophic factor family with specific protective properties on dopaminergic neurons, as shown in 6-hydroxydopamine (6-OHDA) animal models of PD [50]. Furthermore, they seem to act more effectively than GDNF and use a different protective mechanism [51].

\section{Neurotrophins and growth factors in neurodegeneration}

In both AD and PD human brains, levels of BDNF [52] and its mRNA [53] are low. Furthermore, BDNF serum levels correlate with AD severity [54]. Correlated alteration in TrkB expression in AD is also reported in cortical neurons, but not in glial cells, which, surprisingly, upregulate a truncated form of the receptor [55]. According to Tong et al., BDNF signaling pathway seems also to be negatively affected in $\mathrm{AD}$, by $\mathrm{A} \beta$ 1-42 peptide interference with gene transcription. Treatment of rat cortical neurons cultures with sublethal doses of $A \beta$ peptide, interfered with the CREB activation-induced transcription of the BDNF gene and suppressed BDNFinduced activation of selective signaling pathways such as Ras-MAPK/ERK and PI3-K/Akt [56].
The reports regarding NGF mRNA and protein levels in AD brain are contradictory [57-59]. NGF deficiency has been proposed as ethiopatogenic factor in sporadic $\mathrm{AD}$, and the AD11 anti-NGF mice recreate the phenotype and the functional impairment of early AD stages [55]. Also, in early stages, a loss of TrkA has been reported [60], while Cuello et Bruno proposed the existence of a failure of the NGF maturation cascade in AD [61]. A $\beta$ load recreates the same NGF "dismetabolism" in the hippocampus of laboratory rats, as proposed by Cuello et al. [62]. In vitro models showed $A \beta$ peptide as a potent NGF -secretion stimulator in astrocytic rat cultures and, in turn, NGF was shown to increase neurotoxic potency of amyloid peptide in primary rat hippocampal cultures via p75 induction [63].

It is well documented that brains of PD patients express lower GDNF levels [64] and growth factor delivery in brain of PD animal models exerts neuroprotective effects and improves clinical outcome $[65,66]$. Furthermore, Sun et al. demonstrated in a rat model that GDNF is more efficient than BDNF in protecting striatal neurons from 6-hydroxydopamine (6-OHDA), compared to the control group or BDNF group. Moreover, simultaneous administration of both growth factors showed no benefit over GDNF treatment alone [67]. However, using vector-induced striatal neuron-restricted expression of both GDNF and BDNF genes, Cao et al. reported an improved protein expression as to either approach alone [68].

In human $\mathrm{AD}$ studies, there are controversial reports of GDNF protein levels. Straten et al. reported higher CSF concentration than age-matched controls along with decreased serum concentration [69], whereas Marksteiner's et al. results showed increased plasma levels in $\mathrm{AD}$ and mild cognitive impairment (MCI) patients [70]. However, in light of the serious side effects reported after intracerebroventricular infusion of GDNF in parkinsonian patients [71], attention was drown toward MANF and CDNF, which will hopefully make good candidates for novel therapies in PD.

\section{Neuroplasticity in neurodegeneration}

Neuroplasticity is a comprehensive term that illustrates the brain's capacity to adapt, structurally and functionally, to environmental enhancement. According to Thickbroom and Mastaglia, the molecular mechanisms underlying neuroplasticity are both neuronal and nonneuronal and, furthermore, neuronal plasticity may be synaptic or non-synaptic [72]. Neuroplasticity is substrate for learning and memory formation, cognitive abilities progressively lost in $\mathrm{AD}$ and in late stages of $\mathrm{PD}$.

Synaptic loss is one of the neurobiological hallmarks of AD, from the first stages of the disease [73]. The synaptic dysfunction is apparently due to soluble $A \beta$ 
oligomers, as proven by studies on human AD brains [74] and AD animal models [75]. Soluble A $\beta$ oligomers have a proven inhibitory effect on NMDA-R - dependent LTP [76], impairing even further the neuroplasticity, besides their roles in morphological and structural degeneration of the synapse [77].

Synapse alteration is initially compensated by "dynamic synaptic reorganization", emphasized by a paradoxical initial increase in synaptic markers [78]. The proof of network reorganization is sustained by studies on AD brains showing increased polysialylated neural cell adhesion molecule (PSA-NCAM) in dentate gyrus, as compared to controls [79]. Also investigating NCAM, Jørgensen et al hypothesize that AD brain uses neuroplasticity as a compensatory measure for neuronal loss [80]. Furthermore, inflammatory environment - a constant finding in AD brain - impairs neuronal plasticity by inhibiting both (NMDA-R) - induced and voltagedependent calcium channel (VDCC)-induced LTP [81].

The other neuropathological hallmark of AD, tau hyperphosphorylation, correlates with low neuronal plasticity and synaptic disorganization, as proven by studies on hibernating animals [82]. Possibly a protective mechanism against neuronal apoptosis in unfavorable conditions, persistent hyperphosphorylation will eventually lead to formation of paired helical filaments and cell destruction.

PD animal models also show impaired neuroplasticity. Studies in mice overexpressing human $\alpha$-synuclein report both short-term and long-term altered presynaptic plasticity in the corticostriatal pathway [83]. Transgenic mice bearing mutated $\alpha$-synuclein - (A30P) $\alpha$ synuclein - also showed impaired short-time synaptic plasticity [84] and the (6-OHDA) PD animal models develop defective synaptic plasticity induction [85].
Morphological studies of idiopathic PD brains and PD animal models reported that loss of dopaminergic input on medium spiny neurons of striatum resulted in lowerment of dendritic length, dendritic spine density, and total number of dendritic spines [86].

To conclude so far, there is evidence of impaired neural plasticity in both AD [87] and PD [86] brains, which occurs on various molecular levels, from growth factors signaling to synaptic malfunction, disorganization and cytoskeletal rearrangement. However, the brain possesses a latent recovery capacity and in early stages some compensatory mechanisms are triggered (see Table 1). Furthermore, the brain's capacity to compensate these structural and functional deficits is exploited by neurorestoration attempts in animal models and patients, as discussed below.

\section{Neurorestoration}

At the base of initial neurorestoration attempts lies the idea of enhancing the endogenous neuroprotective effect of growth factors in the CNS. At first, genetically modified fibroblasts to produce either BDNF, or NGF have been transplanted in laboratory rats $[88,89]$ and primates [90]. The experiments were successful in rescuing functional and cellular loss. The same type of experiment was conducted, in 2005, on human patients, diagnosed with AD [91]. The delivery system consisted of induced pluripotent stem cells (iPS), generated from the recipient's fibroblast population and genetically modified into secreting NGF. The authors reported significant progress at 22 months follow-up, quantified by cognitive scales and PET -Scan.

For PD patients, there are reports since the 1980's of fetal midbrain dopamine cells implants [92]. The clinical

Table 1 Evidences of impaired neuroregeneration in AD and PD

\begin{tabular}{|c|c|c|c|}
\hline $\begin{array}{l}\text { Neurorestorative } \\
\text { field }\end{array}$ & & Evidence of impairment & Evidence of compensatory mechanism \\
\hline \multirow[t]{2}{*}{ Neurogenesis } & $\mathrm{AD}$ & Decreased number of NPCs and altered division rates [21] & Increased neuroproliferation markers [16] \\
\hline & PD & Reduced number of NPCs [28] & Increased number of PSA-NCAM + cells [29] \\
\hline \multirow[t]{6}{*}{ Neuroprotection } & $A D$ & Low BDNF mRNA and protein levels [37] & Upregulation of glial truncated TrkB [40] \\
\hline & & Controversed data on NGF levels $[40,48,49]$ & $\begin{array}{l}\text { Possibly upregulation of NGF with ageing and } \\
\text { dementia }[61,62,87]\end{array}$ \\
\hline & & & A $\beta$ stimulates NGF astrocytic secrection [51] \\
\hline & & & High GDNF levels in cerebrospinal fluid \\
\hline & PD & Low BDNF mRNA and protein levels [37] & $\begin{array}{l}\text { BDNF pretreatment protects dopaminergic neurons } \\
\text { [34] }\end{array}$ \\
\hline & & Low GDNF protein levels [66] & \\
\hline \multirow[t]{4}{*}{ Neuroplasticity } & $A D$ & Synaptic loss [77] & "Dynamic synaptic reorganization" [82]. \\
\hline & & $\begin{array}{l}\text { LTP impairment by Abeta oligomers and inflammatory } \\
\text { environment [85] }\end{array}$ & NCAM increase in dentate gyrus [83] \\
\hline & PD & Loss of dendritic spines following loss of dopaminergic input [90] & \\
\hline & & Impaired synaptic plasticity in several models of PD [87-89] & \\
\hline
\end{tabular}


outcome was improved $[93,94]$ and engraftment of transplanted cells was successful $[95,96]$, although some authors questioned the utility of the procedure in older patients [97]. However, two double-blinded, randomized, controlled trials set back the initial positivism, showing cell transplantation to be less effective than deep brain stimulation [98], in preventing recurrent dyskinesia. It seems however, that reported improvement is due to replacement by graft cells of aged brain cells [99], rather than stimulation of the brain's own neurorestorative mechanism.

Other restorative models, tested in vitro or in animal models of $\mathrm{AD}$ and $\mathrm{PD}$, use stem cells therapy: i) embryonic stem cells [100]; ii) embryonic stem cells-derived neurospheres [101]; iii) transdifferentiated stem cells (stem cells forced to differentiate outside their lineage by special growth media and specific stimuli) (e.g. hematopoietic stem cells), or iv) mesenchimal stem cells induced into secreting increased quantities of growth factors [102]. Apel et al. report neuroprotective effects of dental pulp cells co-cultured with hippocampal and mesencephalic rat neurons, in in vitro AD and PD models [103]. Murell et al used human olfactory mucosa-derived neuronal progenitors to obtain dopaminergic neurons and transplant them in a rat PD model brain. The outcome was favorable and no difference was noted between transplants received form healthy donors or from Parkinson patients [104].

\section{Summary}

As expected, most reports incline towards progressive impairment of neuroregeneration resources in $\mathrm{AD}$ and PD brains, as proven on human post-mortem analysis, animal models and in vitro studies. However, due to increased amount of evidence that proper stimulation or supply of growth factors restores some of the cognitive loss and ameliorates behavioral skills, we hypothesize that the brain possess, at least in early and medium stages of disease, a "neuroregenerative reserve", that may be and begins to be, targeted as a therapeutical perspective.

\section{List of abbreviations}

AD: Alzheimer's Disease; PD: Parkinson's Disease; NPCs: neural precursor cells; PSA-NCAM: Polysialylated Neural Cell Adhesion Molecule; BDNF: Brain Derived Nerve Factor; TrkB: tropomyosin-related kinase receptor B; NGF: Nerve Growth Factor; GDNF: Glial Derived Nerve Factor

\section{Acknowledgements}

This paper is supported by the Sectorial Operational Programme Human Resources Development (SOP HRD), financed from the European Social Fund and by the Romanian Government under the contract number POSDRU/89/ 1.5/S/64109 and by the Executive Unit for Financing Higher Education, Research, Development and Innovation - Romania (UEFISCDI), Program 4 (Partnerships in Priority Domains), grant nr. 41-013/2007.

\section{Author details}

'Department of Cellular and Molecular Medicine, 'Carol Davila' University of Medicine and Pharmacy, School of Medicine, 8 Eroilor Sanitari, sector 5, Bucharest 050474, Romania. 'Laboratory of Molecular Medicine, Victor Babeş' National Institute of Pathology, 99-101 Splaiul Independenței, sector 5,
Bucharest 050096, Romania. 'Department of Neurology, 'Iuliu Hatieganu' University of Medicine and Pharmacy, 8, Victor Babeş, Cluj Napoca 400023 , Romania. ${ }^{4}$ Department of Neurology, University Hospital Bucharest, 'Carol Davila' University of Medicine and Pharmacy, 169 Splaiul Independenței, sector 5, Bucharest 050098, Romania.

\section{Authors' contributions}

All authors contributed equally to elaboration of the manuscript, read and approved the final manuscript.

\section{Competing interests}

The authors declare that they have no competing interests.

Received: 5 March 2011 Accepted: 23 June 2011

Published: 23 June 2011

\section{References}

1. Johansson BB: Regeneration and plasticity in the brain and spinal cord. J Cereb Blood Flow Metab 2007, 27:1417-1430.

2. Ramon y Cajal S: The Croonian lecture: La fine structure des centres nerveux. Proc Roy Soc London 1894, 55:444-467.

3. Altman J: Autoradiographic study of degenerative and regenerative proliferation of neuroglia cells with tritiated thymidine. Exp Neurol 1962, 5:302-318.

4. Altman J: Are new neurons formed in the brains of adult mammals? Science 1962, 135:1127-1128.

5. Altman J, Das GD: Autoradiographic and histological evidence of postnatal hippocampal neurogenesis in rats. J Comp Neurol 1965, 124:319-335.

6. McKay R: Stem cells in the central nervous system. Science 1997, 276:66-71.

7. Morshead CM, Reynolds BA, Craig CG, McBurney MW, Staines WA, Morassutti D, Weiss S, van der Kooy D: Neural stem cells in the adult mammalian forebrain: a relatively quiescent subpopulation of subependymal cells. Neuron 1994, 13:1071-1082.

8. Reynolds BA, Weiss S: Generation of neurons and astrocytes from isolated cells of the adult mammalian central nervous system. Science 1992, 255:1707-1710.

9. Shihabuddin LS, Palmer TD, Gage FH: The search for neural progenitor cells: prospects for the therapy of neurodegenerative disease. Mol Med Today 1999, 5:474-480

10. Lee $\mathrm{E}$, Son H: Adult hippocampal neurogenesis and related neurotrophic factors. BMB Rep 2009, 42:239-244.

11. Chuang TT: Neurogenesis in mouse models of Alzheimer's disease. Biochim Biophys Acta 2010.

12. Haughey NJ, Nath A, Chan SL, Borchard AC, Rao MS, Mattson MP: Disruption of neurogenesis by amyloid beta-peptide, and perturbed neural progenitor cell homeostasis, in models of Alzheimer's disease. $J$ Neurochem 2002, 83:1509-1524.

13. Kolecki R, Lafauci G, Rubenstein R, Mazur-Kolecka B, Kaczmarski W, Frackowiak J: The effect of amyloidosis-beta and ageing on proliferation of neuronal progenitor cells in APP-transgenic mouse hippocampus and in culture. Acta Neuropathol 2008, 116:419-424

14. Calafiore M, Battaglia G, Zappala A, Trovato-Salinaro E, Caraci F, Caruso M, Vancheri C, Sortino MA, Nicoletti F, Copani A: Progenitor cells from the adult mouse brain acquire a neuronal phenotype in response to betaamyloid. Neurobiol Aging 2006, 27:606-613.

15. Chen $Y$, Dong C: Abeta40 promotes neuronal cell fate in neural progenitor cells. Cell Death Differ 2009, 16:386-394.

16. Sotthibundhu A, Li QX, Thangnipon W, Coulson EJ: Abeta(1-42) stimulates adult SVZ neurogenesis through the p75 neurotrophin receptor. Neurobiol Aging 2009, 30:1975-1985.

17. Jin K, Peel AL, Mao XO, Xie L, Cottrell BA, Henshall DC, Greenberg DA: Increased hippocampal neurogenesis in Alzheimer's disease. Proc Natl Acad Sci USA 2004, 101:343-347.

18. Li B, Yamamori H, Tatebayashi Y, Shafit-Zagardo B, Tanimukai H, Chen S, Iqbal K, Grundke-lqbal I: Failure of neuronal maturation in Alzheimer disease dentate gyrus. J Neuropathol Exp Neurol 2008, 67:78-84.

19. Boekhoorn K, Joels M, Lucassen PJ: Increased proliferation reflects glial and vascular-associated changes, but not neurogenesis in the presenile Alzheimer hippocampus. Neurobiol Dis 2006, 24:1-14. 
20. Verwer RW, Sluiter AA, Balesar RA, Baayen JC, Noske DP, Dirven CM, Wouda J, van Dam AM, Lucassen PJ, Swaab DF: Mature astrocytes in the adult human neocortex express the early neuronal marker doublecortin. Brain 2007, 130:3321-3335.

21. Ziabreva I, Perry E, Perry R, Minger SL, Ekonomou A, Przyborski S, Ballard C: Altered neurogenesis in Alzheimer's disease. J Psychosom Res 2006, 61:311-316.

22. Lovell MA, Geiger H, Van Zant GE, Lynn BC, Markesbery WR: Isolation of neural precursor cells from Alzheimer's disease and aged control postmortem brain. Neurobiol Aging 2006, 27:909-917.

23. Mazur-Kolecka B, Golabek A, Nowicki K, Flory M, Frackowiak J: Amyloid-beta impairs development of neuronal progenitor cells by oxidative mechanisms. Neurobiol Aging 2006, 27:1181-1192.

24. Waldau B, Shetty AK: Behavior of neural stem cells in the Alzheimer brain. Cell Mol Life Sci 2008, 65:2372-2384.

25. Lie DC, Dziewczapolski G, Willhoite AR, Kaspar BK, Shults CW, Gage FH: The adult substantia nigra contains progenitor cells with neurogenic potential. J Neurosci 2002, 22:6639-6649.

26. Liu BF, Gao EJ, Zeng XZ, Ji M, Cai Q, Lu Q, Yang H, Xu QY: Proliferation of neural precursors in the subventricular zone after chemical lesions of the nigrostriatal pathway in rat brain. Brain Res 2006, 1106:30-39.

27. Aponso PM, Faull RL, Connor B: Increased progenitor cell proliferation and astrogenesis in the partial progressive 6-hydroxydopamine model of Parkinson's disease. Neuroscience 2008, 151:1142-1153.

28. Nuber S, Petrasch-Parwez E, Winner B, Winkler J, von Horsten S, Schmidt T, Boy J, Kuhn M, Nguyen HP, Teismann P, Schulz JB, Neumann M, Pichler BJ, Reischl G, Holzmann C, Schmitt I, Bornemann A, Kuhn W, Zimmermann F, Servadio A, Riess O: Neurodegeneration and motor dysfunction in a conditional model of Parkinson's disease. J Neurosci 2008, 28:2471-2484.

29. Hoglinger GU, Rizk P, Muriel MP, Duyckaerts C, Oertel WH, Caille I, Hirsch EC: Dopamine depletion impairs precursor cell proliferation in Parkinson disease. Nat Neurosci 2004, 7:726-735.

30. Borta A, Hoglinger GU: Dopamine and adult neurogenesis. J Neurochem 2007, 100:587-595

31. Auld DS, Mennicken F, Quirion R: Nerve growth factor rapidly induces prolonged acetylcholine release from cultured basal forebrain neurons: differentiation between neuromodulatory and neurotrophic influences. $J$ Neurosci 2001, 21:3375-3382.

32. Baquet ZC, Bickford $P C$, Jones KR: Brain-derived neurotrophic factor is required for the establishment of the proper number of dopaminergic neurons in the substantia nigra pars compacta. J Neurosci 2005, 25:6251-6259.

33. Klein R: Role of neurotrophins in mouse neuronal development. FASEB 1994, 8:738-744.

34. Davies AM, Minichiello L, Klein R: Developmental changes in NT3 signalling via TrkA and TrkB in embryonic neurons. EMBO J 1995, 14:4482-4489.

35. Conover JC, Yancopoulos GD: Neurotrophin regulation of the developing nervous system: analyses of knockout mice. Rev Neurosci 1997, 8:13-27.

36. Cohen-Cory S, Kidane AH, Shirkey NJ, Marshak S: Brain-derived neurotrophic factor and the development of structural neuronal connectivity. Dev Neurobiol 70:271-288.

37. Mattson MP: Neuroprotective signaling and the aging brain: take away my food and let me run. Brain Res 2000, 886:47-53.

38. Cole GM, Frautschy SA: The role of insulin and neurotrophic factor signaling in brain aging and Alzheimer's Disease. Exp Gerontol 2007 42:10-21.

39. Peterson AL, Nutt JG: Treatment of Parkinson's disease with trophic factors. Neurotherapeutics 2008, 5:270-280.

40. Lanni C, Stanga S, Racchi M, Govoni S: The expanding universe of neurotrophic factors: therapeutic potential in aging and age-associated disorders. Curr Pharm Des 16:698-717.

41. Reichardt LF: Neurotrophin-regulated signalling pathways. Philos Trans $R$ Soc Lond B Biol Sci 2006, 361:1545-1564.

42. Volosin M, Song W, Almeida RD, Kaplan DR, Hempstead BL, Friedman WJ: Interaction of survival and death signaling in basal forebrain neurons: roles of neurotrophins and proneurotrophins. J Neurosci 2006, 26:7756-7766.

43. Piltonen M, Bespalov MM, Ervasti D, Matilainen $T$, Sidorova YA, Rauvala $H$, Saarma M, Mannisto PT: Heparin-binding determinants of GDNF reduce its tissue distribution but are beneficial for the protection of nigral dopaminergic neurons. Exp Neurol 2009, 219:499-506.

44. Oo TF, Kholodilov N, Burke RE: Regulation of natural cell death in dopaminergic neurons of the substantia nigra by striatal glial cell linederived neurotrophic factor in vivo. J Neurosci 2003, 23:5141-5148.
45. Bilang-Bleuel A, Revah F, Colin P, Locquet I, Robert JJ, Mallet J, Horellou P. Intrastriatal injection of an adenoviral vector expressing glial-cell-linederived neurotrophic factor prevents dopaminergic neuron degeneration and behavioral impairment in a rat model of Parkinson disease. Proc Natl Acad Sci USA 1997, 94:8818-8823.

46. Eslamboli A, Georgievska B, Ridley RM, Baker HF, Muzyczka N, Burger C, Mandel RJ, Annett L, Kirik D: Continuous low-level glial cell line-derived neurotrophic factor delivery using recombinant adeno-associated viral vectors provides neuroprotection and induces behavioral recovery in a primate model of Parkinson's disease. J Neurosci 2005, 25:769-777.

47. Sariola H, Saarma M: Novel functions and signalling pathways for GDNF. Cell Sci 2003, 116:3855-3862.

48. Jain S, Golden JP, Wozniak D, Pehek E, Johnson EM Jr, Milbrandt J: RET is dispensable for maintenance of midbrain dopaminergic neurons in adult mice. J Neurosci 2006, 26:11230-11238

49. Kramer ER, Aron L, Ramakers GM, Seitz S, Zhuang X, Beyer K, Smidt MP, Klein $R$ : Absence of Ret signaling in mice causes progressive and late degeneration of the nigrostriatal system. PLOS Biol 2007, 5:e39.

50. Voutilainen MH, Back S, Porsti E, Toppinen L, Lindgren L, Lindholm P, Peranen J, Saarma M, Tuominen RK: Mesencephalic astrocyte-derived neurotrophic factor is neurorestorative in rat model of Parkinson's disease. J Neurosci 2009, 29:9651-9659.

51. Lindholm $\mathrm{P}$, Voutilainen $\mathrm{MH}$, Lauren J, Peranen J, Leppanen VM Andressoo JO, Lindahl M, Janhunen S, Kalkkinen N, Timmusk T, Tuominen RK, Saarma M: Novel neurotrophic factor CDNF protects and rescues midbrain dopamine neurons in vivo. Nature 2007, 448:73-77.

52. Mattson MP: Glutamate and neurotrophic factors in neuronal plasticity and disease. Ann N Y Acad Sci 2008, 1144:97-112.

53. Tapia-Arancibia L, Aliaga E, Silhol M, Arancibia S: New insights into brain BDNF function in normal aging and Alzheimer disease. Brain Res Rev 2008, 59:201-220.

54. Laske C, Stransky E, Leyhe T, Eschweiler GW, Wittorf A, Richartz E, Bartels M, Buchkremer G, Schott K: Stage-dependent BDNF serum concentrations in Alzheimer's disease. J Neural Transm 2006, 113:1217-1224.

55. Schindowski K, Belarbi K, Buee L: Neurotrophic factors in Alzheimer's disease: role of axonal transport. Genes Brain Behav 2008, 7(Suppl 1):43-56.

56. Tong L, Balazs R, Thornton PL, Cotman CW: Beta-amyloid peptide at sublethal concentrations downregulates brain-derived neurotrophic factor functions in cultured cortical neurons. J Neurosci 2004, 24:6799-6809.

57. Hefti F: Development of effective therapy for Alzheimer's disease based on neurotrophic factors. Neurobiol Aging 1994, 15(Suppl 2):S193-194.

58. Mufson EJ, Ikonomovic MD, Styren SD, Counts SE, Wuu J, Leurgans S, Bennett DA, Cochran EJ, DeKosky ST: Preservation of brain nerve growth factor in mild cognitive impairment and Alzheimer disease. Arch Neurol 2003, 60:1143-1148.

59. O'Bryant SE, Hobson V, Hall JR, Waring SC, Chan W, Massman P, Lacritz L, Cullum CM, Diaz-Arrastia R: Brain-derived neurotrophic factor levels in Alzheimer's disease. J Alzheimers Dis 2009, 17:337-341.

60. Counts SE, Nadeem M, Wuu J, Ginsberg SD, Saragovi HU, Mufson EJ: Reduction of cortical TrkA but not p75(NTR) protein in early-stage Alzheimer's disease. Ann Neurol 2004, 56:520-531.

61. Cuello AC, Bruno MA: The failure in NGF maturation and its increased degradation as the probable cause for the vulnerability of cholinergic neurons in Alzheimer's disease. Neurochem Res 2007, 32:1041-1045.

62. Cuello AC, Bruno MA, Allard S, Leon W, lulita MF: Cholinergic involvement in Alzheimer's disease. A link with NGF maturation and degradation. J Mol Neurosci 2010, 40:230-235.

63. Schulte-Herbruggen O, Hamker U, Meske V, Danker-Hopfe H, Ohm TG, Hellweg R: Beta/A4-Amyloid increases nerve growth factor production in rat primary hippocampal astrocyte cultures. Int J Dev Neurosci 2007, 25:387-390.

64. Chauhan NB, Siegel GJ, Lee JM: Depletion of glial cell line-derived neurotrophic factor in substantia nigra neurons of Parkinson's disease brain. J Chem Neuroanat 2001, 21:277-288.

65. Eberling $J$, Kells AP, Pivirotto P, Beyer J, Bringas J, Federoff HJ, Forsayeth J, Bankiewicz KS: Functional effects of AAV2-GDNF on the dopaminergic nigrostriatal pathway in parkinsonian rhesus monkeys. Hum Gene The 2009, 20:511-518

66. Ericson C, Georgievska B, Lundberg C: Ex vivo gene delivery of GDNF using primary astrocytes transduced with a lentiviral vector provides 
neuroprotection in a rat model of Parkinson's disease. Eur J Neurosci 2005, 22:2755-2764.

67. Sun $M$, Kong L, Wang X, Lu XG, Gao Q, Geller Al: Comparison of the capability of GDNF, BDNF, or both, to protect nigrostriatal neurons in a rat model of Parkinson's disease. Brain Res 2005, 1052:119-129.

68. Cao H, Zhang GR, Wang X, Kong L, Geller Al: Enhanced nigrostriatal neuron-specific, long-term expression by using neural-specific promoters in combination with targeted gene transfer by modified helper virusfree HSV-1 vector particles. BMC Neurosci 2008, 9:37.

69. Straten G, Eschweiler GW, Maetzler W, Laske C, Leyhe T: Glial cell-line derived neurotrophic factor (GDNF) concentrations in cerebrospinal fluid and serum of patients with early Alzheimer's disease and normal controls. J Alzheimers Dis 2009, 18:331-337.

70. Marksteiner J, Kemmler G, Weiss EM, Knaus G, Ullrich C, Mechteriakov S, Oberbauer $H$, Auffinger S, Hinterholzl J, Hinterhuber H, Humpel C: Five out of 16 plasma signaling proteins are enhanced in plasma of patients with mild cognitive impairment and Alzheimer's disease. Neurobiol Aging 2009.

71. Nutt JG, Burchiel $\mathrm{K}$, Comella $\mathrm{CL}$, Jankovic J, Lang $\mathrm{AE}$, Laws ER Jr, Lozano AM, Penn RD, Simpson RK Jr, Stacy M, Wooten GF: Randomized, double-blind trial of glial cell line-derived neurotrophic factor (GDNF) in PD. Neurology 2003, 60:69-73.

72. Thickbroom GW, Mastaglia FL: Plasticity in neurological disorders and challenges for noninvasive brain stimulation (NBS). J Neuroeng Rehabil 2009, 6:4.

73. Arendt T: Synaptic degeneration in Alzheimer's disease. Acta Neuropathol 2009, 118:167-179.

74. Walsh DM, Selkoe DJ: Deciphering the molecular basis of memory failure in Alzheimer's disease. Neuron 2004, 44:181-193.

75. Rowan MJ, Klyubin I, Cullen WK, Anwyl R: Synaptic plasticity in animal models of early Alzheimer's disease. Philos Trans R Soc Lond B Biol Sci 2003, 358:821-828

76. Lacor PN, Buniel MC, Furlow PW, Clemente AS, Velasco PT, Wood M, Viola KL, Klein WL: Abeta oligomer-induced aberrations in synapse composition, shape, and density provide a molecular basis for loss of connectivity in Alzheimer's disease. J Neurosci 2007, 27:796-807.

77. Gong Y, Chang L, Viola KL, Lacor PN, Lambert MP, Finch CE, Krafft GA Klein WL: Alzheimer's disease-affected brain: presence of oligomeric A beta ligands (ADDLs) suggests a molecular basis for reversible memory loss. Proc Natl Acad Sci USA 2003, 100:10417-10422.

78. Arendt T, Bruckner MK: Linking cell-cycle dysfunction in Alzheimer's disease to a failure of synaptic plasticity. Biochim Biophys Acta 2007, 1772:413-421.

79. Mikkonen M, Soininen H, Tapiola T, Alafuzoff I, Miettinen R: Hippocampal plasticity in Alzheimer's disease: changes in highly polysialylated NCAM immunoreactivity in the hippocampal formation. Eur J Neurosci 1999, 11:1754-1764.

80. Jorgensen OS, Brooksbank BW, Balazs R: Neuronal plasticity and astrocytic reaction in Down syndrome and Alzheimer disease. J Neurol Sci 1990, 98:63-79.

81. Min SS, Quan HY, Ma J, Han JS, Jeon BH, Seol GH: Chronic brain inflammation impairs two forms of long-term potentiation in the rat hippocampal CA1 area. Neurosci Lett 2009, 456:20-24.

82. Arendt T, Stieler J, Strijkstra AM, Hut RA, Rudiger J, Van der Zee EA, Harkany T, Holzer M, Hartig W: Reversible paired helical filament-like phosphorylation of tau is an adaptive process associated with neuronal plasticity in hibernating animals. J Neurosci 2003, 23:6972-6981.

83. Watson JB, Hatami A, David H, Masliah E, Roberts K, Evans CE, Levine MS: Alterations in corticostriatal synaptic plasticity in mice overexpressing human alpha-synuclein. Neuroscience 2009, 159:501-513.

84. Steidl JV, Gomez-Isla T, Mariash A, Ashe KH, Boland LM: Altered short-term hippocampal synaptic plasticity in mutant alpha-synuclein transgenic mice. Neuroreport 2003, 14:219-223.

85. Picconi B, Ghiglieri V, Bagetta V, Barone I, Sgobio C, Calabresi P: Striatal synaptic changes in experimental parkinsonism: role of NMDA receptor trafficking in PSD. Parkinsonism Relat Disord 2008, 14(Suppl 2):S145-149.

86. Deutch AY, Colbran RJ, Winder DJ: Striatal plasticity and medium spiny neuron dendritic remodeling in parkinsonism. Parkinsonism Relat Disord 2007, 13(Suppl 3):S251-258

87. Mufson EJ, Kordower $\mathrm{JH}$ : Cortical neurons express nerve growth factor receptors in advanced age and Alzheimer disease. Proc Natl Acad Sci USA 1992, 89:569-573.
88. Chen KS, Gage FH: Somatic gene transfer of NGF to the aged brain: behavioral and morphological amelioration. J Neurosci 1995, 15:2819-2825

89. Frim DM, Uhler TA, Galpern WR, Beal MF, Breakefield XO, Isacson O: Implanted fibroblasts genetically engineered to produce brain-derived neurotrophic factor prevent 1-methyl-4-phenylpyridinium toxicity to dopaminergic neurons in the rat. Proc Natl Acad Sci USA 1994, 91:5104-5108.

90. Smith DE, Roberts J, Gage FH, Tuszynski MH: Age-associated neuronal atrophy occurs in the primate brain and is reversible by growth factor gene therapy. Proc Natl Acad Sci USA 1999, 96:10893-10898.

91. Tuszynski MH, Thal L, Pay M, Salmon DP, U HS, Bakay R, Patel P, Blesch A, Vahlsing HL, Ho G, Tong G, Potkin SG, Fallon J, Hansen L, Mufson EJ, Kordower JH, Gall C, Conner J: A phase 1 clinical trial of nerve growth factor gene therapy for Alzheimer disease. Nat Med 2005, 11:551-555.

92. Bradford HF: The use of foetal human brain tissue as brain implants: phenotype manipulation by genetic manipulation and biochemical induction. Keio J Med 2002, 51:148-153.

93. Defer GL, Geny C, Ricolfi F, Fenelon G, Monfort JC, Remy P, Villafane G, Jeny $R$, Samson $Y$, Keravel $Y$, Gaston A, Degos JD, Peschanski M, Cesaro P, Nguyen JP: Long-term outcome of unilaterally transplanted parkinsonian patients. I. Clinical approach. Brain 1996, 119(Pt 1):41-50.

94. Hauser RA, Freeman TB, Snow BJ, Nauert M, Gauger L, Kordower JH, Olanow CW: Long-term evaluation of bilateral fetal nigral transplantation in Parkinson disease. Arch Neurol 1999, 56:179-187.

95. Mendez I, Sanchez-Pernaute R, Cooper O, Vinuela A, Ferrari D, Bjorklund L, Dagher A, Isacson O: Cell type analysis of functional fetal dopamine cell suspension transplants in the striatum and substantia nigra of patients with Parkinson's disease. Brain 2005, 128:1498-1510.

96. Mendez I, Vinuela A, Astradsson A, Mukhida K, Hallett P, Robertson H, Tierney $T$, Holness R, Dagher A, Trojanowski JQ, Isacson O: Dopamine neurons implanted into people with Parkinson's disease survive without pathology for 14 years. Nat Med 2008, 14:507-509

97. Freed CR, Greene PE, Breeze RE, Tsai WY, DuMouchel W, Kao R, Dillon S, Winfield H, Culver S, Trojanowski JQ, Eidelberg D, Fahn S: Transplantation of embryonic dopamine neurons for severe Parkinson's disease. $N$ Engl J Med 2001, 344:710-719

98. Geraerts M, Krylyshkina O, Debyser Z, Baekelandt V: Concise review: therapeutic strategies for Parkinson disease based on the modulation of adult neurogenesis. Stem Cells 2007, 25:263-270.

99. Barzilay R, Levy YS, Melamed E, Offen D: Adult stem cells for neuronal repair. Isr Med Assoc J 2006, 8:61-66.

100. Bjorklund LM, Sanchez-Pernaute R, Chung S, Andersson T, Chen IY, McNaught KS, Brownell AL, Jenkins BG, Wahlestedt C, Kim KS, Isacson O: Embryonic stem cells develop into functional dopaminergic neurons after transplantation in a Parkinson rat model. Proc Natl Acad Sci USA 2002, 99:2344-2349.

101. Wang Q, Matsumoto Y, Shindo T, Miyake K, Shindo A, Kawanishi M, Kawai N, Tamiya T, Nagao S: Neural stem cells transplantation in cortex in a mouse model of Alzheimer's disease. J Med Invest 2006, 53:61-69.

102. Sadan O, Shemesh N, Cohen Y, Melamed E, Offen D: Adult neurotrophic factor-secreting stem cells: a potential novel therapy for neurodegenerative diseases. Isr Med Assoc J 2009, 11:201-204.

103. Apel C, Forlenza OV, de Paula VJ, Talib LL, Denecke B, Eduardo CP, Gattaz WF: The neuroprotective effect of dental pulp cells in models of Alzheimer's and Parkinson's disease. J Neural Transm 2009, 116:71-78.

104. Murrell W, Wetzig A, Donnellan M, Feron F, Burne T, Meedeniya A, Kesby J, Bianco J, Perry C, Silburn P, Mackay-Sim A: Olfactory mucosa is a potential source for autologous stem cell therapy for Parkinson's disease. Stem Cells 2008, 26:2183-2192

\section{Pre-publication history}

The pre-publication history for this paper can be accessed here: http://www.biomedcentral.com/1471-2377/11/75/prepub

doi:10.1186/1471-2377-11-75

Cite this article as: Enciu et al:: Neuroregeneration in neurodegenerative disorders. BMC Neurology 2011 11:75 